\title{
Stress and Coping Strategies Amongst Islamic Education Novice Teachers
}

\author{
Tengku Sarina Aini Tengku Kasim \\ Islamic Education Programme, Academy of Islamic Studies, \\ University of Malaya, 50603 Kuala Lumpur. Malaysia.tgsarina@um.edu.my \\ Azizah Abdul Majid \\ Academy of Islamic Studies, University of Malaya, \\ 50603 Kuala Lumpur. Malaysia. azizah55@siswa.um.edu.my \\ DOI: https://doi.org/10.22452/usuluddin.vol48no2.7
}

\begin{abstract}
Studies have shown that teaching profession is considered to be a highly stressful career and this can lead to teachers suffering from burnout. Teachers from many countries reported high levels of stresses, particularly, novice teachers who seem to be more vulnerable to the pressures of the profession compared to experienced teachers. Thus, in order to fill in the voids in the existing teacher stress literature, the present study aims to investigate factors contributing to stress among Islamic Education novice teachers during their early years of teaching and their coping strategies to minimize the pressure. This study was conducted on a number of Islamic education novice teachers in secondary schools from four different states in Malaysia. The data were acquired by using semistructured individual interviews. Insight into these factors and coping strategies can serve as significant guidance in laying out support for novice teachers' professional development.
\end{abstract}

Keywords: Islamic education novice teachers; stress coping strategies, Islamic perspectives

\section{Introduction}

For centuries, teaching has been characterized as a profession that is "emotionally taxing and potentially frustrating". The rate at which teachers leave the profession is significantly higher than the departure rate in other professions within the first five years of teaching ${ }^{2}$. Because of the high teacher attrition rates within the first five years of their career, this vulnerable time is "an opportunity lost

1 R., Lambert et al., "Teacher Stress and Classroom Structural Characteristics in Preschool Settings" In Understanding Teacher Stress in an Age of Accountability, Ed. R. Lambert \& C. McCarthy (Greenwich, CT: Information Age, 2006), 105.

2 Melanie M. Minarik, Bill Thornton, and George Perreault, "Systems Thinking Can Improve Teacher Retention”, Clearing House 76, no. 5 (2003): 230-234. 
for the health of the teaching profession"3. This vulnerability can be attributed to the fact that they transition from being a student to being a teacher. Studies showed that they felt stress and pressure in carrying out their duties because there exists big difference between being student teachers and working as real teachers in the real working environment ${ }^{4}$.

Novice teachers seem to be more vulnerable to the pressures of the profession compared to experienced teachers. There are a variety of personal, climate and professional factors that often join forces to make their first year of teaching challenging. These include the focus on new teaching roles, the change from students to teaching, loneliness, non-supportive cultures in the school, instructional challenges and ineffective teaching activities. Novice teachers tend to feel exhausted with the extent of their responsibility during the first month of training. These feelings remain as the demands of everyday lesson planning, marking, grading, parentteacher meetings, curriculum meetings and student behaviour management seem endless 5 .

There is a volume of published studies that documented topics related to novice teachers. Novice teachers have diverse backgrounds, motivations, experiences and level of training in their early teaching experience, and these factors influence their roles and responsibilities. Analyses by a study conducted by Fitchett $e t$ al. in year 2018, cautiously indicate that the possibility of stress from first-year teachers was correlated with trends across vocational issues comparable to results found with more experienced teachers in their previous studies. They found that new stress-risk teachers faced greater threats to their workplace, seemed more vulnerable to burnout, and reported less teaching dedication than resourced

3 National Council on Teacher Quality, State Teacher Policy Yearbook: What States Can Do to Retain Effective New Teachers (Washington, DC: Author, 2008), 111-116.

4 James C. Conroy, Betwixt and Between: The Liminal Imagination, Education and Democracy (New York: Peter Lang, 2004). 379-382.

5 M. H. Dali, Zainudin Abu Bakar and J. Skudai, Coping with Stress: An Investigation of Novice Teacher's Stressor About Socially Just Teaching In Seminar Kebangsaan Majlis Dekan Pendidikan IPT, Pendidikan (2012). 117. 
peers. ${ }^{6}$ In 2017, Arif et al. carried-out a research to examine the influence of emotional quotient (EQ) towards novice teachers' work stress and organizational commitment in the northern part of Malaysia $^{7} .3$ study instruments were used in their study such as Emotional Evaluation Scale, Teachers' Stress Inventory and Organization Commitment questionnaires. The survey was done through stratified random sampling and simple sampling where the sample study comprised of 325 novice teachers who have served between 1 to 3 years. The analysis showed there is influence of EQ towards commitment and work stress and influence of stress on organizational commitment through SEM analysis. Work stress also proved to be the mediator in the relationship between EQ and organizational commitment.

The following subjects are debated and concerned with novice teachers' implementation of teaching and learning inside and outside the classroom, insufficient classroom management ${ }^{8}$, building their social relationships with colleagues or administrators, as well as administrative work to be done besides teaching ${ }^{9}$. Several other studies identified setting up the classroom, preparing for the first week of school, curriculum expectation, salary and the maintenance of personal sanity as matters which considered the greatest difficulties for novice teachers. A study summarized that novice teachers were grappled with: (1) lack of experiences and confidences, and unable to manage their classroom; (2) facing difficulties understanding the best way to teach and suit with their students; and (3) theoretically know how to evaluate students, but incapable to practice it in reality ${ }^{10}$.

6 Paul G. Fitchett et al., "An Examination of US First-Year Teachers' Risk For Occupational Stress: Associations with Professional Preparation and Occupational Health", Teachers and Teaching 24, no. 2 (2018): 99-11.

7 Arif, Zakaria Mohd, Arumugam Raman, and Yahya Don, "The Influence of Emotional Quotient (EQ) Towards Novice Teachers' Work Stress and Organizational Commitment. International Journal of Academic Research and Development 2, no. 2 (2017):11-17.

8 Senol Sezer, 'Novice Teachers' Opinions on Students' Disruptive Behaviours: A Case Study", Eurasian Journal of Educational Research 69 (2017): 199-219.

9 Robert D. Fantilli and Douglas E. McDougall, "A Study of Novice Teachers: Challenges and Supports in the First Years," Teaching and Teacher Education 25 (2009): 814-825.

10 Melek Çakmak, "Learning from Teaching Experiences: Novice Teachers' Thoughts", H. U. Journal of Education Special Is, no. 1 (2013): 55-67. 
On the other hand, in Finland, the obstacles affecting novice teachers' sense of professional agency, the findings showed that novice teachers discerned many limitations in developing the pedagogical practices such as lack of facilities and time-consuming during preparation and planning ${ }^{11}$. Saeedeh Shohani et al. mentioned that novice teachers have a low self-esteem and inferior, hence, rate their performance low due to their inability to control one or two problematic students ${ }^{12}$. Sharplin et al., argued that the degree of stress faced by beginning teachers should not be underestimated. The fact that 20 per cent of the participants in their study left their appointment during the first six months, rising to more than 40 per cent at the end of one year, indicates that the participants encountered a high degree of distress during the period. Three additional participants submitted and withdrew resignations during their studies and two participants repeatedly considered alternate career opportunities. In total, almost 60 per cent of the participants were sufficiently unhappy with the quality of their work life to suggest the termination of their jobs at some point. ${ }^{13}$

An individual perceives stress in accordance with one's own adaptation to the environment, which may vary from another person's point of view. It is followed by physiological responses of the body and emotional experiences that trigger tension and excitement, the long term of which may have negative implications for the human body and health. Stress is a complex interaction between coping mechanisms, personality traits and environment. Thus "teachers with high levels of stress are more likely to use negative coping strategies such as escape avoidance" ${ }^{14}$. According

11 Eteläpelto, Anneli, Katja Vähäsantanen, and Päivi Hökkä. "How Do Novice Teachers in Finland Perceive Their Professional Agency?" Teachers and Teaching: Theory and Practice 21, no. 6 (2015): 660-680. https://doi.org/http:// dx.doi.org/10.1080/13540602.2015.1044327.

12 Shohani, Saeedeh, Akbar Azizifar, Habib Gowhary, and Ali Jamalinesari. "The Relationship between Novice and Experienced Teachers' Self-Efficacy for Personal Teaching and External Influences", Procedia - Social and Behavioral Sciences 185 (2014): 446-452.

13 Sharplin, Elaine, Marnie O’Neill, and Anne Chapman. "Coping Strategies for Adaptation to New Teacher Appointments: Intervention for Retention", Teaching and Teacher Education 27, no. 1 (2011): 136-146.

14 Vicky Austin, S. Shah, and S. Muncer, "Teacher Stress and Coping Strategies Used to Reduce Stress", Occupational Therapy International 12, no. 2 (2005): 73 
to Chan and Hui ${ }^{15}$ avoidance and distancing strategies are associated with: withdrawal from stress sources; emotional exhaustion; depersonalisation; and lack of accomplishment. They are less likely to produce positive psychological outcomes for individuals. Chan further concluded that avoidant coping strategies increased psychological symptoms of stress "perpetuating a vicious cycle of escalating stress and symptoms"16. He recommended managing stress by confronting and appraising stressors and adopting active coping strategies rather than using avoidant strategies.

Thus, the purpose of this study is to examine factors contributing to stress among Islamic Education novice teachers and their ways to cope with it. For teachers, experiencing a high level of stress seems to be detrimental for their well-being and may indirectly harm students' achievement ${ }^{17}$. It also seems to influence their intension of leaving the profession/attrition ${ }^{18}$, their decision to leave teaching ${ }^{19}$ and their teaching quality ${ }^{20}$. In addition, negative effects of stress include lack of employment, poor employee morale, high injuries at employment, reduced productivity, increased medical funding. ${ }^{21} \mathrm{Kim}$ et al. investigated the role of the stress mindset of teacher and the relationship to the turnover of their job. More than 300 Korean teachers studied whether their mental

15 David W. Chan, and Eadaoin K. P. Hui, "Burnout and Coping Among Chinese Secondary School Teachers in Hong Kong", British Journal of Educational Psychology 65, no. 1 (1995): 15-25.

16 David W. Chan, "Stress, Coping Strategies, and Psychological Distress Among Secondary School Teachers in Hong Kong", American Educational Research Journal 35, no.1 (1998): 159.

17 M. Ronfeldt, S. Loeb and J. Wyckoff, "How Teacher Turnover Harms Student Achievement", American Educational Research Journal 50 (2013), 4-36.

18 Nathan Jones and Peter Youngs, "Attitudes and Affect: Daily Emotions and Their Association with the Commitment and Burnout of Beginning Teachers", Teachers College Record 114 (2012): 1-36.

19 Melissa Newberry and Yvonne Allsop, "Teacher Attrition in the USA: The Relational Elements in a Utah Case Study", Teachers and Teaching 23 (2017): 863-880.

20 Rubina Hanif, “Teacher Stress, Job Performance and Self-Efficacy of Women School Teachers" (PhD thesis, National Institute of Psychology, Quaid-e-Azam University, Islamabad, Pakistan), 2004.

21 Mohd Juraimy Hj, Kadir and Ahmad Azan Ridzuan, "Strategi Menguruskan Tekanan dari Perspektif Islam (Stress Management Strategy in Islamic Perspective)", Jurnal Hadhari: An International Journal 6, no. 1 (2014): 27-41. 
stress at the beginning of the school year had an impact on their success during the school year. They find that teachers who can see the positive side of stress felt less stress at work and less likely to be out of work after a year than their colleagues who perceived stress as strictly negative. Interestingly, these connections have been significant even in terms of race, teaching experience, monthly salary and class size. Their alternative model testing has shown that the thinking of teachers plays a significant role in perceived job stress rather than the other way around. ${ }^{22}$

\section{The Stress of Life}

Jon, Randy and De Simone ${ }^{23}$ defined stress as a situation which affects an individual to feel pressured in one's daily life, whereas Moss defined stress as one situation or a change in working environment which could result in disaster, full of threats, challenges or frustrations which would change the life of the individual ${ }^{24}$.

According to Selye stress is the unspecific reaction of the body to any demands made on it. Every living being is constantly under stress and something, good or negative, that speeds up the intensity of life, causes a temporary increase in stress, wear and tear on the body. Contrary to common belief, stress is not simply nervous tension or the product of injury. Stress is not, above all, something that actually needs to be avoided. It is correlated with the manifestation of all the inherent drives of the body. Stress exists as long as there is a demand from some part of the body. Death is, in fact, a complete freedom from stress. ${ }^{25}$

Life exists by maintaining a complex dynamic balance, or homeostasis, which is constantly challenged by an intrinsic or extrinsic adverse force or stressor. Stress is thus defined as a state of threatened homeostasis that is re-established by a complex

22 Joungyoun Kim et al., "Stress Mindset Predicts Job Turnover Among Preschool Teachers", Journal of School Psychology 78 (2020): 13-22.

${ }^{23}$ Randy L Jon MW and J De Simone, Human Resourse Development (5 ${ }^{\text {th }}$ Ed., New York: Cengage Learning, 2009).

24 Charles A. Moss, "Power of the Five Elements: Path to Healthy Aging and Stress Resistance" retrieved on April 20, 2010, http:///northatindiabooks, wordpress.com.

25 Hans Selye, "Stress without Distress" In Psychopathology of Human Adaptation (Boston, MA: Springer, 1976), pp. 137-146. 
repertoire of physiological and behavioural adaptive reactions of the organism. $^{26}$

Selye identified four stress indicators, i.e., irritability, loss of anxiety, insomnia, and had enough. ${ }^{27} \mathrm{He}$ then indicated that changes in the body cause the brain cortex (part of the brain to think) to signal a danger to the hypothalamus (midbrain). At that time, there is a stimulation to the nervous system that induces changes in the body's system, including a rapid rise in heart rate, a rise in blood pressure and a smooth sweating of the body. He mentioned that when stress is out of balance, the adrenal glands secrete corticosteroids that cause digestive and immune system. ${ }^{28}$

Seyle indicated that changes in the body cause the brain cortex (part of the brain to think) to signal a danger to the hypothalamus (midbrain). At that time, there is a stimulation to the nervous system that induces changes in the body's system, including a rapid rise in heart rate, a rise in blood pressure and a smooth sweating of the body. He mentioned that when stress is out of balance, the adrenal glands secrete corticosteroids that cause digestive and immune system disorders. ${ }^{29}$

Stress also exists in school environment caused by change and additional responsibility to the teachers ${ }^{30}$. The experience of unpleasant emotions such as tension, frustration, anxiety, anger and depression are described as teacher stress ${ }^{31}$. Sustained high levels of stress resulted in teacher burnout and resignation. ${ }^{32}$ High teacher

26 George P. Chrousos, "Stressors, Stress, and Neuroendocrine Integration of the Adaptive Response: The 1997 Hans Selye Memorial Lecture", Annals of the New York Academy of Sciences 851, no. 1 (1998): 311-335.

27 Hans Selye, "A personal Message from Hans Selye", Journal of Extension 18, no. 3 (1980): 6-11.

28 Hans Selye, "Stress without Distress" In Psychopathology of Human Adaptation, pp. 137-146.

29 Mohd Juraimy Hj Kadir and Ahmad Azan Ridzuan, "Strategi Menguruskan Tekanan dari Perspektif Islam (Stress Management Strategy in Islamic Perspective)", Jurnal Hadhari: An International Journal 6, no. 1 (2014): 27-41.

30 Dewenter J and Kruger P. "Primary Teachers", Psychology Bulletin 78 (2009): 109-132.

31 C. Kyriacou, and J. Sutcliffe, "Teacher Stress: Prevalence, Sources and Symptoms", British Journal of Educational Psychology 48(1978): 159-167.

32 H. Pillay, R. Goddard, and L. Wilss, "Well-being, Burnout and Competence: Implications for Teachers", Australian Journal of Teacher Education 30, no. 2 (2005): 22-33. 
stress was mediated through different means of coping and personality traits ${ }^{33}$. Kim et al. investigated the role of the stress mindset of teacher and the relationship to the turnover of their job. More than 300 Korean teachers studied whether their mental stress at the beginning of the school year had an impact on their success during the school year. They find that teachers who can see the positive side of stress felt less stress at work and less likely to be out of work after a year than their colleagues who perceived stress as strictly negative. Interestingly, these connections have been significant even in terms of race, teaching experience, monthly salary and class size. Their alternative model testing has shown that the thinking of teachers plays a significant role in perceived job stress rather than the other way around. ${ }^{34}$

\section{Stress from Islamic Perspective}

Research has shown that religious commitment and faith are correlated with many good things. Results include, but not limited to, increased capacity to cope with stress, reduced incidence of depression and anxiety, reduced risk of suicide and criminal behaviour, and reduced use of tobacco, drugs and alcohol. ${ }^{35}$

Islam is known to be a way of life rather than just an organised religion because of its systematic existence. Guidance is given for many areas of life, including the spiritual, family, social, political and economic aspects process. ${ }^{36}$ The implementation of the Islamic teachings is crucial to meet the demands of the human nature of a person, without neglecting the biological and psychological aspects. ${ }^{37}$ Since spirituality and faith are fundamental to the lives of Muslims, it is beneficial to include these aspects in the study of

33 David W. Chan, "Stress, Coping Strategies, and Psychological Distress Among Secondary School Teachers Iin Hong Kong", American Educational Research Journal 35, no.1 (1998): 145-163.

34 Joungyoun Kim et al., "Stress Mindset Predicts Job Turnover Among Preschool Teachers", Journal of School Psychology 78 (2020): 13-22.

35 David B. Larson et al., "Associations Between Dimensions of Religious Commitment and Mental Health Reported in The American Journal of Psychiatry and Archives of General Psychiatry: 1978-1989", American Journal of psychiatry 149, no. 4 (1992): 557-559.

36 Aisha Hamdan, "Cognitive Restructuring: an Islamic Perspective", Journal of Muslim Mental Health 3, no. 1 (2008): 99-116.

37 Nurul Sakinah Aziz et al., "Psycho-Spiritual Treatment: An Exploratory Study on its Practices", Journal of Critical Reviews 7, no. 8 (2020): 1007-1011. 
stress, particularly from an Islamic perspective. It is not only necessary for professionals working with Muslim clients to develop an understanding of Islamic faith and practise, but also to incorporate culturally relevant and efficient techniques into the process. $^{38}$

According to al-Ghazali in his book Ihya' Ulum al-Din, all human acts, whether conscious or not, are based on the soul and the heart. ${ }^{39}$ The heart serves to feel, to know and to recognise, and the heart is also the recipient of God's commands and prohibitions. Consequently, the heart is also the location where tension or stress exists in humans. Any type of stress or pressure a human being can experience, it must be resolved in some way, because if left alone, it will cause harm to health and, in turn, impact the quality of everyday life. ${ }^{40}$ Safe and Nor mentioned that the soul that characterises the body or the muscles, and if it is frail, is the source of stress. Soul is also called the "Jawähir", the life force, and the spirit. From the point of view of Sufism, the soul may know God, but life does not. Therefore, the power of the soul is seen by its relationship with God, the greater the relationship of the soul with God, the harder it is to be disrupted by the devil. ${ }^{41}$

It is the essence of this life that people will suffer from worry and stress, for this world is the place of sickness, misery and pain. Among the aspects that separate Heaven from this world, however, is the fact that there is no worry or stress therein: "No sense of fatigue shall touch them, nor shall they (ever) be asked to leave." [al-Hijr 15:48 - interpretation of the meaning]. Nothing ever upsets the people of Heaven, not even the slightest word: "They will hear no "laghw" (dirty, fake, bad, vain talk) or some sinful speech (like backbiting, etc.), but only the saying of Salaam! Oh, Salaam! [alWāqi'ah 56:25-26 - interpretation of the meaning]. ${ }^{42}$

38 Aisha Hamdan, "Cognitive Restructuring: an Islamic Perspective", Journal of Muslim Mental Health 3, no. 1 (2008): 99-116.

39 Abu Hamid Muhammad bin Muhammad bin Ahmad al-Ghazali, Ihya' 'Ulum al-Din, terj. Jiwa Agama (Cet. 6, Indonesia: Penerbit Asli, 1980), jilid 1.

40 Nor Azah Abdul Aziz, "Kaedah Menangani Stres dengan Solat", Journal of Islamic and Arabic Education 3, no. 2 (2011): 1-10.

41 Siti Noorshafenas Safe dan Ahmad Yunus Mohd. Nor, "Pengurusan Stres Menurut Al-Quran dan Hadith", Al-Hikmah 8, no. 1 (2016): 3-18.

42 Muhammed Salih Al-Munajjid, "Dealing with Worries and Stress", www. islam-qa. com/index. php (2006). 1-32. 
A true believer would consider anything that happens to him, or threatens him, to be a test from God. Often the test comes in the form of a human being or an obstacle, God is the one who has created a human being or an obstacle, and God is the one who moves the person to do whatever it is. The reality of the test is that it comes from God, and if a person believes the test comes from the creature, they will feel narrow and depress, but if the test is from the Almighty Creator, then it is easy to treat others with forgiveness. Every believer must acknowledge that the test comes from alHakim, who must have the wisdom behind it. This can be demonstrated by the proofs of the Quran below.

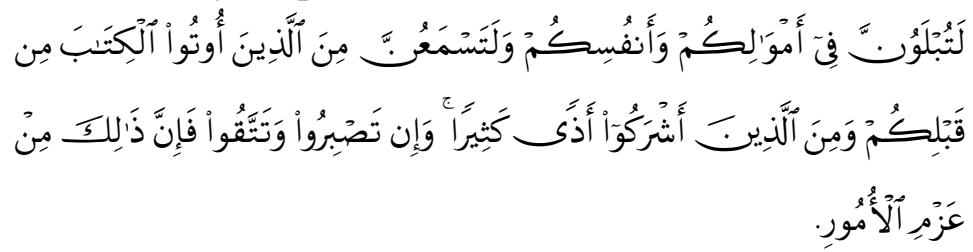

Ali-Imran 3:186

Translation: (Believers!) You will certainly be put to test in respect of your properties and lives, and you will certainly hear many hurtful things from those who were granted the Book before you and those who have associated others with Allah in His divinity. If you remain patient and God-fearing this indeed is a matter of great resolution.

Surah al-Baqarah 2:214 reminds man that there will be no exception in life to trials and tribulations. All these difficulties can give rise to stress, either eustress or distress. ${ }^{43}$

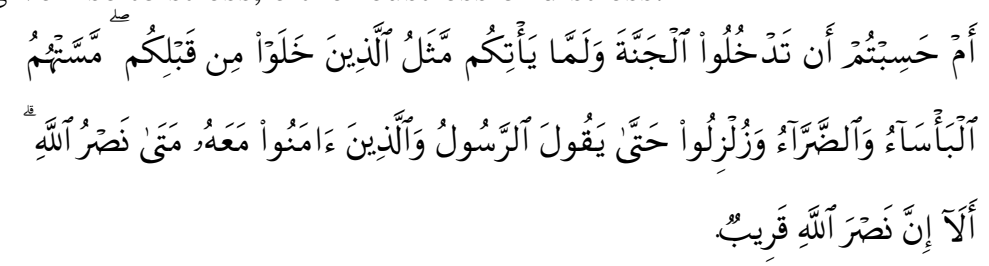

Al-Baqarah 2:214

Translation: Do you suppose that you will enter Paradise untouched by the suffering endured by the people of faith who

43 Mohd Juraimy Hj Kadir and Ahmad Azan Ridzuan, "Strategi Menguruskan Tekanan dari Perspektif Islam (Stress Management Strategy in Islamic Perspective)", Jurnal Hadhari: An International Journal 6, no. 1 (2014): 27-41. 
passed away before you? They were afflicted by misery and hardship and were so convulsed that the Messenger and the believers with him cried out: "When will Allah's help arrive?" They were assured: "Behold, Allah's help is close by."

From the two verses listed above, it can be concluded that any human being will be tested by numerous challenges and obstacles to find the best candidate to fulfil the Paradise of Allah s.w.t. Allah's tests also include slander and hurtful accusations. In the face of this challenge, a believer will discover different circumstances that can cause a person to feel stress. As a believer, one must be careful and righteous, for Allah would not waste his deeds.

Maryam bint 'Imran experienced a great deal of stress and anxiety when she got pregnant without getting married. Her distress came to such a point that: "...she said: 'Would that I had died before this and had been forgotten and out of sight!" [Maryam 19:23 interpretation of the meaning]. She talked like this because she knew that people would blame her and not believe her when she came to them with a child in her arms, because she had been one of the dedicated female worshippers who lived in seclusion near the mosque, and she had come from a rather religious family and was descended from the Prophets. Because of all this, she bore such a great burden of anxiety that she wished she had died before this happened to her, or that she had been "forgotten and out of reach," that is, she had never been born at all. ${ }^{44}$ Maryam bint "Imran, one of the chief women in heaven, was tested so great, and then her rank was raised in the hereafter.

In all consciences, the absolute submission can only be to the God Allah. For this cause, the most important thing is that a Muslim must have faith in Allah s.w.t. and that all trials come from Allah s.w.t. in order to be rewarded in the Hereafter. It is clearly mentioned in Surah At Taghabun, verse 11.

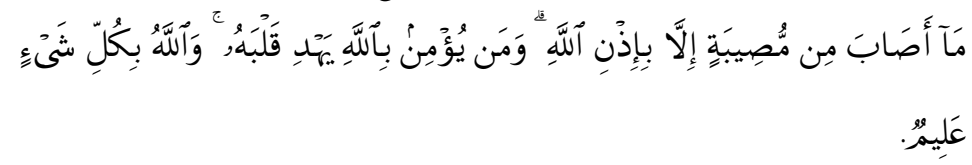

Al-Taghābun 64:11

44 Muhammed Sali Al-Munajjid, "Dealing with Worries and Stress", www.islamqa.com/index. php (2006). 
Translation: "No calamity befalls anyone except by Allah's Will. And whoever has faith in Allah, He will rightly guide their hearts through adversity. And Allah has perfect knowledge of all things."

And Allah knows all things. Even though Muslim has to face stress as part of the tribulation of life, being vigilant means willing with the assurance that Allah has prearranged. With prayer, human beings often seek the safety and guidance of Allah in all problems and circumstances. ${ }^{45}$ The religious belief of a person has an important influence on his or her personality and view of life. By believing God, the believer minimises the burden on himself by reducing his responsibility and the ability to manage his shortcomings and failures. ${ }^{46}$ Regulation his mistakes and complete surrender is only to God (Allah SWT). ${ }^{47}$

\section{Coping Strategies from Islamic Perspectives}

Prior to 1960, the term 'coping' was used with both the medical and societal connotations of the word in terms of positive reactions to stress. Since the 1960s, though, there has been a rise in the amount of focused study on coping. The term 'coping' did not appear in the field of psychology until 1967 and was used in psychoanalysis under the so-called defence mechanism of the subconscious. It was between the sixties and the seventies, however, that researchers started to attach coping strategies to stress, instead of focusing on extreme conditions such as life-threatening or traumatic events. In the 1980s, studies centred on dealing with a range of responses and measurement processes. Stress will establish physiological responses of the body and emotional experiences that trigger tension and excitement, the long term of which may have negative implications for the human body and health.

45 Khatijah Othman and Sapora Sipon, "Researching Solution Based on Islamic Views and Practice in Managing Financial and Work Place Stress", International Journal of Academic Research in Business and Social Sciences 2, no. 8 (2012): 239-252.

46 M.D. Shahid Athar, "Islamic Perspective in Stress Management", retrieve October 5, 2020, https://www.islamicity.org/6575/islamic-perspective-in-stress -management

47 Khatijah Othman and Sapora Sipon, "The Relationship of Financial Stress and Religious Coping from Islamic Perspective", International Review of Management and Business Research 3, no. 1 (2014): 133. 
There are currently different meanings of coping. Coping strategies have been classified as direct-action strategies focused on stress source elimination and palliative strategies which reduce stress by modifying internal or emotional reactions ${ }^{48}$. Positive coping strategies were linked to seeking support, positive appraisal and planful problem-solving. Recently, medical research has evolved very quickly, allowing individuals to regain and meet their wellbeing needs. In an extremely challenging and emotionally distracted environment, the need to have effective and adequate counselling and psychotherapy has made the therapists look for integrated ways to address the challenge. ${ }^{49}$

Recent studies have shown that religious coping strategies contribute to the reduction and buffering of work stressors. Religious coping methods consist of aspects of emotional coping and problem coping strategies. ${ }^{50}$ Nawal et al. mentioned that mental wellbeing was associated with religiosity and psychological resilience $^{51}$. Their studies suggest that religiosity offers support that will allow patients to establish a path for their lives and to deal with the stress of their lives. People with high spiritual intelligence are investing more effort and persisting longer than individuals with low spiritual intelligence. Therefore, it can be expected that those with high spiritual intelligence will use effective or problem-centred coping mechanisms, whereas those with low spiritual intelligence may choose negative emotional strategies. Their study found that cancer is known to be a stressor condition for patients and that it has triggered many mental health issues, such as anxiety and depression at all levels of the cancer spectrum. They believe that every religiosity and psychological stability will help the emotional

48 Vicky Austin, S. Shah, and S. Muncer, "Teacher Stress and Coping Strategies Used to Reduce Stress", Occupational Therapy International 12, no. 2 (2005): 63-80.

49 Siti Chodijah, "The Concept of Tahajud Prayer Through Psychotherapy Approach in Relationship with Psychological Health" In Proceedings of the 1st International Conference on Innovative Pedagogy (Icip) 2017. Stkip Bina Bangsa Getsempena, 2017: 324-330.

50 Achour, Meguellati, Benaouda Bensaid, and Mohd Roslan Mohd Nor, "An Islamic Perspective on Coping with Life Stressors", Applied Research in Quality of Life 11, no. 3 (2016): 663-685.

51 Nawal A. Al Eid et al., "Religiosity, Psychological Resilience, and Mental Health Among Breast Cancer Patients in Kingdom of Saudi Arabia", Breast Cancer: Basic and Clinical Research 14 (2020): 1-13. 
wellbeing of breast cancer. Thus, they highlighted the importance of improving religiosity and psychological stability among cancer patients in Arab countries to improve their mental health.

From Islamic perspective, the stress control strategies outlined by the Quran and Hadith include dhikr, prayer and tadabbur alQuran. Dhikir has been shown to raise spiritual awareness, which in turn influences the improvement of personality so that it can turn negative stress (distress) into positive stress (eustress). Dhikir would also be able to reduce the biological response due to cortisol conversion and increase the personality by producing positive, good and independent behaviour. ${ }^{52}$ Every human being suffering from stress requires calmness, and it can only be accomplished by remembering Allah through dhikir.

Prayer in Arabic is an act of worship that is particular and unique to Islam, both in its form and in its spirit. While the English word prayer conveys a general sense of supplication or invocation, prayer is an act of obedience to the Supreme God, Allah, which is embodied in a particular and well-defined physical act that represents the spirit. This act of worship is prescribed as an obligation to all Muslims and is the second pillar of faith. ${ }^{53}$

In terms of tadabbur the Quran, Ahmed El Kadi of Akbar Clinic, Panama City, Florida, performed and published the effects of listening to the Quranic recitation on physiological criteria, i.e., pulse rate, blood pressure and muscle strain, and reported change in both, regardless of whether the listener is Muslim or non-Muslim, Arab or non-Arab. Obviously, it should be concluded that those who can appreciate and love the recitation, believing in it as the Word of

52 Tri Niswati Utami, "Tinjauan Literatur Mekanisme Zikir Terhadap Kesehatan: Respons Imunitas." JUMANTIK (Jurnal Ilmiah Penelitian Kesehatan) 2, no. 1 (2017): 100-110.

53 Siti Chodijah, "The Concept of Tahajud Prayer Through Psychotherapy Approach in Relationship with Psychological Health" In Proceedings of the 1st International Conference on Innovative Pedagogy (Icip) 2017. Stkip Bina Bangsa Getsempena, 2017. 
God, will have the most benefit. ${ }^{54}$ The recitation of the Holy Quran has a calming effect on the body, mind, and heart of all patients. ${ }^{55}$

\section{Research Design}

Creswell defines qualitative research "as a study which begins with assumptions, a worldview, the possible use of a theoretical lens, and the study of research problems inquiring into the meaning individuals or groups ascribe to a social or human problem" ${ }^{56}$ This coincides with Merriam and Tisdell who stated that the purpose of qualitative research is to understand the meaning that people have constructed.$^{57}$ By reviewing definitions, the curiosity was triggered by an assumption of certain phenomena or situation that conducted and performed by the human. In this research context, researcher opted for qualitative research design in order to explore and identify Islamic Education novice teachers' teaching practices during their early years of services in secondary schools.

\section{Research Sample}

Research participants were amongst secondary school Islamic education novice teachers from four different zones (north, south, east coast and East Malaysia), that were recruited by using purposive sampling. Purposive sampling was applied to identify and select research participants because it enabled the incorporation of the research interest and purpose. ${ }^{58}$ Therefore, ten novice teachers who served less than five years of teaching were chosen to be the main criteria for this study. Pseudonyms are used to preserve the anonymity of the research participants (ISNT Azila, ISNT Borhan, ISNT Elias, ISNT Ghazali, ISNT Hasnita, ISNT

54 M.D. Shahid Athar, Islamic Perspective in Stress Management. Retrieved on October 5, 2020, https://www.islamicity.org/6575/islamic-perspective-in-stress -management (2017).

55 Nawal A. Al Eid et al., "Religiosity, Psychological Resilience, and Mental Health Among Breast Cancer Patients in Kingdom of Saudi Arabia", Breast Cancer: Basic and Clinical Research 14 (2020):1-13.

56 John W. Creswell, Qualitative Inquiry and Research Design: Choosing Among Five Approaches ( $2^{\text {nd }}$ ed., Thousand Oaks, CA: Sage Publications, Inc, 2007), 37.

57 Sharan B Merriam and Elizabeth J Tisdell, Qualitative Research: A Guide to Design and Implementation (4 ${ }^{\text {th }}$ ed., San Francisco: Jossey-Bass, 2016). 3-20.

58 John W. Creswell, Qualitative Inquiry and Research Design: Choosing Among Five Approaches, 117-145. 
Jamaluddin, ISNT Maisarah, ISNT Rohaya, ISNT Intan, and ISNT Kamal).

\section{Research Instruments}

As a method of data collection, semi-structured individual interviews were conducted by having a two-way interaction process to obtain information from research participants. According to Yin, it is a must to have a framework or protocol in order to remain consistent with the objectives of the research. ${ }^{59}$ Therefore, a set of interview protocol had been sent to panel of experts to verify the validity. Other than that, researchers need to maintain flexibility in responding towards any issues that emerge spontaneously while interviewing through dialogue and interactions. In any case, any spontaneous issues are welcomed and researchers are able to redirect the flow back to the research context. All interviews took around 45 to 60 minutes per novice teachers to ensure the data is unique and sufficient.

\section{Data Analysis}

Data from all interviews has been transcribed and for quotation purposes, it was translated from Malay to English. Thus, it comes with a challenge to ensuring the researcher to keep close with the original context. Afterwards, all data were coded and analysed thematically to define differences and repeatable ideas by using Miles and Huberman's Interaction Model. ${ }^{60}$

\section{Findings and Discussions}

The data analysis discusses the qualitative data acquired via interviews with 10 Islamic Education novice teachers with one to three years of teaching experience. The interviews offered some illuminating observations about how they managed their initial challenges.

59 Robert K. Yin, Qualitative Research from Start to Finish (New York: The Guilford Press, 2011). 137-162.

60 Matthew B Miles and A. Michael Huberman, Qualitative Data Analysis, (2 ${ }^{\text {nd }}$ Ed", Thousand Oaks, CA: Sage Publications, Inc, 1994), 107-119. 


\section{Stress with Teaching Condition of Twenty-First Century Education}

The Ministry of Education proposes 21st Century Education (PAK21) which emphasizes a student-centered learning approach and active learning that transforms the role of teachers into facilitators. Teachers act to help students solve problems given to them as a learning process. PAK-21 acknowledges active learning process based on the elements of communication, collaborative, critical thinking, and creativity as well as the application of good values and ethics. ${ }^{61}$ Analysis of past studies proves that student-centered learning approaches can improve the quality of learning as well as attract their interest and motivation to engage in learning sessions. ${ }^{62}$ This approach will increase students' interest and motivation as well as create an active learning environment. ${ }^{63}$

In light of emphasizing $21^{\text {st }}$ century education, novice teachers are expected to be equipped and conducted the teaching and learning process efficaciously as a new educator. As the recent graduates from teacher training programs, their pedagogical theorybased knowledge that they have obtained is imperative in helping them addressing current education affairs. In addition, novice teachers will not only learn how to teach once they entered the school, but they have already encountered with a number of factors that can shape them to be competent educators, such as their socialization process during their first year, previous schooling encounter and teacher training program. ${ }^{64}$

Theoretically, all novice teachers have been exposed with the understanding on teaching and learning during their teaching training. By putting pedagogical practices into focal of the study, it revolves around the appearance of the 21 st century education, a

61 Kementerian Pendidikan Malaysia, Pembelajaran Abad ke-21, p. 102. Retrieved on October 5, 2020.https://ms.wikipedia.org/wiki/Abad_ke-21.

62 Katrien Struyven, Filip Dochy and Steven Janssens, "'Teach as You Preach': The Effects of Student-Centred versus Lecture-Based Teaching on Student Teachers' Approach to Teaching", European Journal of Teacher Education 33, no. 1 (2010): 43-64.

63 Gayle L. Macklem, Boredom in the Classroom: Addressing Student Motivation, Self-Regulation, and Engagement in Learning (New York: Springer, 2015).

64 Thomas S. C. Farrell, "Learning to Teach Language in the First Year: A Singapore Case Study." In Novice Language Teachers: Insights and Perspectives for the First Year, ed. by Thomas S. C. Farrell, 43-56. (London: Equinox Publishing Ltd, 2008). 
technology-friendly that has embodied in the education framework, which comes along with various methods, techniques, strategies, and tools to meet the latest needs. It is also requiring novice teacher to emphasize student as the heart of the learning, and the students can independently construct their knowledge with their current experiences under the guidance of their teachers.

However, novice teachers in this study notably reported that they faced a daunting task in coping with their new roles and responsibilities in the transitioning from student-teachers into inservice teachers. They have encountered huge stress in pedagogical preparation during the early years of their career. In accordance with the twenty-first century education, the novice teachers were envisaged to conduct their teaching and learning process into student-centred learning strategies such as group work, gallery walk, discussion etc. Student-activating teaching is "an approach that stimulates students to construct knowledge by means of real life, realistic, practical and relevant assignments that requiring students' active involvement to incorporate available information". ${ }^{65}$ They also mentioned how they dissatisfied with their teaching techniques and stressed to apply the learning strategies as required by the 21 st century education in their classroom.

I provide opportunities for them to participate in classroom activities such as group works, discussion, presentation, gallery walk, traffic light... and others... as a teacher, I realize it is our role to encourage students to be active ... but it's hard and difficult when they themselves refused to cooperate... so disappointed... most of the time, they preferred to receive information from me rather than to carry out activities by themselves...they still preferred to listen and take notes... (ISNT Faizah)

Of course I know how to use all the methods that are suggested by PAK-21, but if we as teachers do, but students are not interested... not seriously follow what they are told, then we just go back to use the traditional teaching method... teach as

65 Katrien Struyven, Filip Dochy, and Steven Janssens, “"Teach as You Preach': The Effects of Student-Centred versus Lecture-Based Teaching on Student Teachers' Approach to Teaching," European Journal of Teacher Education 33, no. 1 (2010): 44. 
usual, explain the topic, then ask what students do not understand...then explain again and again until they well understand... (ISNT Kamal)

I have tried my best to encourage them being together with me in the learning activities, asked them to choose learning activities related to the lessons, but most of them did not seem interested. Very depressed with their attitudes ... sometimes it feels like a waste of time... For example, I ask them to create an I-think map on their own and do a gallery walk regarding the topic... I've planned various activities, prepared handouts and related articles for the topics, sometimes play some videos, but still not all students motivated to learn... some of them gave all kind of excuses to escape from the activities... (ISNT Rohaya)

The method that teachers should use in PAK-21 such as Gallery Walk, Fan \& Pick, Round Robin are not easy to do in class... it's so difficult to make sure all students can participate well... how do other teachers do about this? feeling stress with their response... (ISNT Intan)

The excerpts above revealed how the teachers tried to help their students to set goals, work together in groups and use all available learning resources as recommended by the 21 st century education. Noticeably, the data found that poor student behaviour is a main contributor to the novice teachers' stress. The data revealed that they are most vulnerable to stress and feelings of dissatisfaction with their roles. ISNT Jamaluddin further reported that she "feels belittled" when some of her students reluctant to involve in any planned PAK-21 learning activities set up by her. ISNT Rohaya commented that her students seemed "enjoyed with those PAK-21 learning strategies, however they didn't contribute well because of unpreparedness...How am I supposed to act in this situation?". As stated by Sorenson, "stress is a condition of twenty-first-century education that continues to increase as more accountability standards and new policy initiatives are introduced." ${ }^{\circ 6}$ Many factors can contribute to high levels of teacher stress, however this study conducted on Islamic Education novice teachers suggests student behaviour is an increasing factor of their stress. The data is in line

66 R. D. Sorenson, "Stress Management in Education: Warning Signs and Coping Mechanisms", Management in Education 21, no. 3 (2007): 12. 
with Geving's research finding. Her study found 10 specific student behaviours to be statistically significant contributors to teacher stress, namely: hostility towards the teacher, not paying attention during class, noisiness, lack of effort in class, coming to class unprepared, hyperactivity, breaking school rules, harming school property, hostility toward other students, and lack of interest in learning. ${ }^{67}$

The novice teachers further reported a variety of frustrations. Other than emphasizing difficulties with managing students, they also commented on overwhelming workload. For example, ISNT Azila said that she "usually work about eleven or twelve hours a day", ISNT Borhan mentioned that "in order to plan effective learning activities, there's been a lot of thirteen-, fourteen-hour days of work". He further explained that in his first year of teaching, the job was very time consuming. Meanwhile, ISNT Maisarah said that:

I did lots of activities in class, such as hot seats, dragon ball, musical chairs etc... I think I've had a significant level of stress for the whole year just for worrying about planning learning activities, how to make sure they learn in class, how to grade them... anything like that.

The data showed the novice teachers believed that the PAK-21 approach is burdensome due to misunderstandings that arise.

They argue the implementation of PAK-21 means a compulsory use of few techniques and methods. This can be observed through their explanations in the interviews that have taken place. They explained their experiences of having difficulties presenting their lesson applying PAK-21 learning methods because students were not interested in engaging in the planned activities. The statements of the teachers seem to reflect their understanding that the pedagogy in PAK-21 obliges teachers to use such methods. Therefore, when they did not get appropriate responses from the students, they felt that they had failed to carry out PAK-21. Their misunderstanding leading to their stress, as factors leading to stress and burnout are often related to the characteristics of being effective

67 Allison M. Geving, "Identifying the Types of Student and Teacher Behaviours Associated with Teacher Stress", Teaching and Teacher Education: An International Journal of Research and Studies 23, no. 5 (2007): 624-640. 
or highly qualified and the pressures related to achieving those goals as well as increased accountability measures for teachers. ${ }^{68}$

This study also found another stressor that contribute to their stress. They reported that in order to support PAK-21, they tried to use technology in the curriculum taught. However, they felt burden when failed to utilize effectively the technology and internet access in learning processes. For example, Teacher Faizah mentioned that I realize that technology can help to encourage students' active participation in the classroom, and different forms of technology can be used to retain students' knowledge. However, I still cannot differentiate which devices can work best for them...

Meanwhile, Teacher Elias explained that he 'tried to use technological approaches such as mobile devices in the classroom, but failed because of time constraint... so frustrated.' ISNT Intan further complained that,

I had a virtual workshop using Google Meet by ICT teachers last month. But I need more time to better understand the contents and methods of the new curriculum... feel depress when cannot use efficiently," said Teacher Intan as a new teacher who started working at the end of 2019.

The data proves that although technology infuses classrooms with digital learning tools, such as computers and hand-held devices, but their application have not well utilized due to several aspects. The factors include lack of training, guidance and exposure related to the provision of teaching aids, technical readiness aspect as well as content suitability elements based on teacher teaching subjects. Despite the advancement of educational technology, highlights of previous studies related to the methods often used by Islamic Education teachers found that they did not apply technological facilities in teaching, instead still choose the method of lecture and traditional teaching.

\section{Devotion to Allah and faith as Stress Coping Strategies}

The beginning five years of teaching experiences for novice teachers was stressful, as they will normally go through trial and error process during this period. Extensive research in various

68 Richard D. Sorenson, "Stress Management in Education: Warning Signs and Coping Mechanisms", Management in Education 21, no. 3 (2007):10-13. 
countries have revealed that novice teachers primarily require assistance in solving practical and technical problems related to their work. The inability of novice teachers to cope with their pressure might lead to stress, burnout, attrition and even unfavourable outcome for their students. Therefore, every novice teacher must acquire the ability to control emotion and stress. Stress is a common condition in the service profession that involves human interaction. In teacher effectiveness, having the opportunity to cope with stressors is important. Novice teachers need not to "sink" but rather recognise stress variables, deals with the problems, and happily "swim" into fulfilling education career. ${ }^{69}$

Teachers cope with stress in school via many different ways, as individuals vary due to their personality traits. The use of appropriate coping strategies helps people manage stress and its effects and if the person applies suitable approaches when confronting stress, the damages caused by stress decrease. This study found the Islamic Education novice teachers choose other ways to confront and manage their stress. They prominently turned to spiritual and religious as their stress coping strategies. During interviews, they reported that they did face stressful situations regarding choosing effective pedagogical methods, setting students' grades and dealing with group of students with great variation in knowledge and skills.

However, they mentioned that they managed to control their stress because they were aware that there is Allah behind everything that takes place. For example, an excerpt from ISNT Azila, "I build up strength to beat the stress, because I know Allah is always with me..." Another teacher said that "I believe Allah is always with us, thus believe in Allah and having faith, it will bring us to being safe and secure..." (ISNT Ghazali). Meanwhile ISNT Hasnita believes that "Allah is just, always put in mind that we were not just being created and then left to live in this world alone... suffering for nothing." For teacher Jamaluddin, "When stressed, I always tell myself that things eventually will get better with Allah's help and guidance..." Similar with this, ISNT Maisarah said, "I rarely lose

69 Michelle Taylor, et al., "The Influence of Multiple Life Stressors During Teacher Training on Burnout and Career Optimism in the First Year of Teaching”, Teaching and Teacher Education 86 (2019): 1-11. 
hope, even if I get disappointed, I know that I have Allah to who has promised to help me..."

As Muslim teachers, their philosophy and knowledge of Islam have guided them in building their characters and personalities. High-moral personality from Islamic perspective includes values, characteristics, qualities, manners and social graces, and ' $a d a b$ ' (etiquette). The basis of Islamic personality can be seen as one of absolute devotion to God and faith (Islam). Thus, a person who embraces religious beliefs has a meaningful effect on his or her personality and outlook on life. In fact, the individual removes the areas of stress and anxiety in his or her personality. The faith in Allah and its other aspects such as cognitive, value, attitude, behavioural and emotional aspects lead to cultivation of other characteristics including self-esteem, internal control, and selfefficiency in individuals guiding them to be resistant to the unpleasant events and stress. ${ }^{70}$

The participants reported that when they experienced unpleasant and negative emotions resulting from some aspects of their works, they used spiritual and religious resources to soothe themselves. Religious practices such as meditation, prayers and reading sacred texts, made individuals regain many influences on their level of motivation and decrease the feeling of anxiety and depression and brings them closer the God simultaneously. ${ }^{71}$ The followings are several excerpts from the interviews;

By having real faith, it provides me a sense of trust in Allah, I have less fear on the uncertainties and difficulties... (ISNT Hasnita)

I try to relieve my stress by reflecting on myself, thinking back my past mistakes as 'muhasabah' before sleep every night (ISNT Faizah)

Recite verses from the Quran and Hadith... that nice feeling of reading the Quran as I know that the Creator of the whole universe is mindful of us...so relaxing (ISNT Maisarah)

70 AA A Mokhtari SK Tabatabaei, "Relationship Between Religious Orientation with Stress", J Psychol 5, no. 17 (2001): 56-67.

71 K.I. Pargament, Spiritually Integrated Psychotherapy: Understanding and Addressing the Sacred (New York: Guilford, 2007), 94-128. 
The last thing I think of when I'm stressed out with works deadline and complicated school projects is to get on my knees... (ISNT Borhan)

Whenever experiencing stress, I will pray to Allah... ask for assistance while performing dhikr and reciting Yasin... (ISNT Ghazali)

I have stressful life as a beginning teacher, but I think I'm greatly satisfied... sometimes when I'm struggling with my jobs, I compare myself with other relatives and friend, who are still unemployed... then I believe, that I have a better situation... so yes, I am stressed, but I'm doing good... thanks to Allah, alhamdulillah... (ISNT Elias)

Their strategies were in line with Islamic teaching and narrations, that the faith in Allah should be the primary and most efficient approach to achieve the inner peace and the control over anxiety and stress. This supports a growing body of research studies that suggests spirituality and prayer rank high among the best stress busters. Contemporary researchers asserted that the religious practise has become foremost strategies in coping and handling the stress and difficulties, as individuals would have stronger relationship with God through their numerous engagements in spiritual connectedness. ${ }^{72}$

Asian literature proved that religious practices resulted better health conditions and well-beings to respondents and subjects who experienced stressful situations. Referring to nurse and medical practitioner, Jannati et al. ${ }^{73}$ argue that nurses in Brunei performed Islamic religious practices as methods in managing their stress. Their findings found that through Islamic practices such as reading the Holy Quran, respondents able to exercise much calmness situation towards nurses' capacities in handling heavy and extraordinary workloads. In another study in Indonesia, Triantoro ${ }^{74}$

72 Ramly Radzi et al., "Religious and Spiritual Coping Used by Student in Dealing with Stress and Anxiety", International Journal of Asian Social Science 4 (2014): 314-319.

73 Yadollah Jannati, R. Mohamadi and N. Seyedfatehmi, "Iranian Clinical Nurses' Coping Strategies Related to Job Stress", Journal of Occupational Health 53 (2011): 123-129.

74 S. Triantoro, "Are Leadership Practices, Role Stressor, Religious Coping, and Job Insecurity Predictors of Job Stress Among University Teachers? A 
found that religious practices provide much guidance to Indonesian academics in coping stress which consequently improves their wellbeing, even elevated their morale and spiritual connectedness with God.

A study by Norhafizah and Che Zarrina, addressing the effect of Islamic psychotherapy as a treatment and coping mechanism to overcome stress among chronic breast cancer patients. Most of them may have prolonged stress during recovery or even in their everyday lives. The purpose of their descriptive qualitative research study was to address aspects of stress encountered by the patient. They found that the establishment of an Islamic psychotherapy module could assist to relieve stress in patients. Patients encounter mental disorders, particularly those suffering from feared diseases such as breast cancer, will benefit from this Islamic psychotherapy treatment ${ }^{75}$. Moreover, Jafari's study found that students with intrinsic religious orientation use the problem-oriented coping strategies more than the students with extrinsic religious orientation. The students with extrinsic religious orientation use the emotion-oriented coping strategies more than the students with intrinsic religious orientation ${ }^{76}$. A religious model of stress management in line with Quran and Hadith has been developed by Yousef Aazami and Esfandiar Azad Marzabadi. Their study applies qualitative method adopting the conventional content analysis of the verses of Quran and Hadith. The analysis resources include the Holy Quran, Mizan al-Hikmah, Usul al-Kafi and Thematic Interpretation of the Holy Quran by Javadi Amoli. According to the analysis of the verses of Quran and Islamic traditions, they divided stress management strategies into four general methods: cognitive, behavioral, emotional and multiple-way strategies. Among the cognitive methods: belief in the wisdom of Allah and having stability with insight; among behavioral methods or strategies: patience, praying, repentance, forgiveness, reading the Quran and

Moderated-mediated Model”, International Journal of Research Studies in Psychology 3 (2014): 87-99.

75 Norhafizah Musa and Che Zarrina Sa'ari, "Pendekatan Psikoterapi Islam dalam Menguruskan Tekanan Pesakit Kronik”, Jurnal Usuluddin 47, no. 1 (2019): 134.

76 A. Jafari, "Examine the Relationship Between Religious Orientation (internally and externally) with Coping Styles in Students", J behav sci 1, no. 1 (2009): 91114. 
being obedient to the commands of Allah in the Quran; among emotional strategies: fear of Allah, humbleness before Allah, having hope when involvement; and among the multi-way methods: stress management and the strategies to trust in Allah, remembrance of Allah, virtue, praying and charity are respectively the best strategies for stress management. ${ }^{77}$

\section{Conclusion}

Teachers deal with a wide variety of stress elements on a daily basis. Studies have shown that teaching is a stressful career and without proper handling, this may lead to teachers suffering from burnout, as well as negative implications towards their mental performance and well-beings. Novice teachers are particularly vulnerable, but this research shows that Islamic education novice teachers are able to take care and cope with their stress effectively.

\section{Acknowledgement}

Researchers would like to thank Institute of Research Management and Monitoring, University of Malaya for granting the research grants. This paper is resulted from research funded by GPF004L2019.

\section{References}

A Mokhtari AA, SK Tabatabaei. "Relationship Between Religious Orientation with Stress". J Psychol 5, no. 17 (2001): 56-67. Abdul Aziz, Nor Azah. "Kaedah Menangani Stres Dengan Solat". Journal of Islamic and Arabic Education 3, no. 2 (2011): $1-10$.

Achour, Meguellati, Benaouda Bensaid, and Mohd Roslan Mohd Nor. "An Islamic Perspective on Coping with Life Stressors". Applied Research on Quality of Life 11, no. 3 (2016): 663-685.

Al Eid, Nawal A., et al. "Religiosity, Psychological Resilience, and Mental Health Among Breast Cancer Patients in Kingdom of Saudi Arabia". Breast Cancer: Basic and Clinical Research 14 (2020): 1-13.

77 Yousef Aazami and Esfandiar Azad Marzabadi, "Stress Management Model Pattern According to Quran and Hadith", Int J Behav Sci 10, no. 4 (2017): 167175. 
Al-Ghazali, Abu Hamid Muhammad bin Muhammad bin Ahmad. Ihya' 'Ulum al-Din, terj. Jiwa Agama. Cet. 6, Indonesia: Penerbit Asli, 1980.

Al-Munajjid, Muhammed Salih. "Dealing with Worries and Stress". www.islam-qa.com/index. php (2006).

Austin, Vicky, Shah, S. and Muncer, S. "Teacher Stress and Coping Strategies Used to Reduce Stress". Occupational Therapy International 12, no. 2 (2005): 63-80.

Çakmak, Melek. "Learning from Teaching Experiences: Novice Teachers' Thoughts," H. U. Journal of Education Special Is no. 1 (2013): 55-67.

Chan, D. W. "Stress, Coping Strategies, and Psychological Distress Among Secondary School Teachers in Hong Kong". American Educational Research Journal 35, no. 1 (1998): 145-163.

Chan, David W. and Hui, E. K. P. "Burnout and Coping Among Chinese Secondary School Teachers in Hong Kong". British Journal of Educational Psychology 65, no. 1 (1995):15-25.

Chrousos, George P. "Stressors, Stress, and Neuroendocrine Integration of The Adaptive Response: The 1997 Hans Selye Memorial Lecture". Annals of the New York Academy of Sciences 851, no. 1 (1998): 311-335.

Conroy, James C. Betwixt and Between: The Liminal Imagination, Education and Democracy. New York: Peter Lang, 2004.

Dali, M. et al. Coping with Stress: An Investigation of Novice Teacher's Stressor About Socially Just Teaching. In Seminar Kebangsaan Majlis Dekan Pendidikan IPT, Pendidikan (2012).

Dewenter J and Kruger P. "Primary Teachers". Psychology Buletin 78 (2009): 109-132.

Eteläpelto, Katja Vähäsantanen, and Päivi Hökkä. "How Do Novice Teachers in Finland Perceive Their Professional Agency?" Teachers and Teaching: Theory and Practice 21, no. 6 (2015): 660-680. https://doi.org/http://dx.doi.org/10.1080/13540602.20 15.1044327.

Fantilli, Robert D. and McDougall, Douglas E. "A Study of Novice Teachers: Challenges and Supports in the First Years," Teaching and Teacher Education 25 (2009): 814-825.

Farrell, Thomas S. C. "Learning to Teach Language in the First Year: A Singapore Case Study." In Novice Language Teachers: 
Insights and Perspectives for the First Year, edited by Thomas S. C. Farrell, 43-56. London: Equinox Publishing Ltd, 2008.

Fitchett, Paul G., et al. "An Examination of US First-Year Teachers' Risk for Occupational Stress: Associations with Professional Preparation and Occupational Health". Teachers and Teaching 24, no. 2 (2018): 99-118

Geving, Allison M. "Identifying the Types of Student and Teacher Behaviours Associated with Teacher Stress". Teaching and Teacher Education: An International Journal of Research and Studies 23, no. 5 (2007): 624-640.

H. Pillay, R. Goddard, and L. Wilss. "Well-being, Burnout and Competence: Implications for Teachers", Australian Journal of Teacher Education 30, no.2 (2005): 22-33.

Hamdan, Aisha. "Cognitive Restructuring: An Islamic perspective". Journal of Muslim Mental Health 3, no. 1 (2008): 99-116.

Hanif, Rubina. "Teacher Stress, Job Performance and Self-Efficacy of Women School Teachers". PhD thesis, National Institute of Psychology, Quaid-e-Azam University, Islamabad, Pakistan, 2004.

Jafari A, "Examine the Relationship Between Religious Orientation (internally and externally) with Coping Styles in Students", $J$ behav sci 1, no. 1 (2009): 91-114.

John W. Creswell, Qualitative Inquiry and Research Design: Choosing Among Five Approaches. $2^{\text {nd }}$ ed.,Thousand Oaks, CA: Sage Publications, Inc, 2007.

Jon MW, Randy L, De Simone, J. Human Resource Development, $5^{\text {th }}$ Ed., New York: Cengage Learning, 2009.

Jones, Nathan and Youngs, Peter. "Attitudes and Affect: Daily Emotions and Their Association with the Commitment and Burnout of Beginning Teachers", Teachers College Record 114 (2012): 1-36.

Kementerian Pendidikan Malaysia. Pembelajaran Abad ke-21 https://ms.wikipedia.org/wiki/Abad_ke-21

Kim, Joungyoun et al. "Stress Mindset Predicts Job Turnover Among Preschool Teachers", Journal of School Psychology 78 (2020): 13-22. 
Kyriacou, C. and Sutcliffe, J. "Teacher Stress: Prevalence, Sources and Symptoms", British Journal of Educational Psychology 48(1978): 159-167.

Lambert, R. et al. "Teacher Stress and Classroom Structural Characteristics in Preschool Settings" In Understanding Teacher Stress in an Age of Accountability, Ed. R. Lambert \& C. McCarthy. Greenwich, CT: Information Age, 2006.

Larson, David B. et al., "Associations Between Dimensions of Religious Commitment and Mental Health Reported in the American Journal of Psychiatry and Archives of General Psychiatry: 1978-1989", American Journal of Psychiatry 149, no. 4 (1992): 557-559.

Macklem, Gayle L. Boredom in the Classroom: Addressing Student Motivation, Self-Regulation, and Engagement in Learning. New York: Springer, 2015.

Merriam, Sharan B and Tisdell, Elizabeth J. Qualitative Research: A Guide to Design and Implementation. $4^{\text {th }}$ ed., San Francisco: Jossey-Bass, 2016).

Miles, Matthew B and Huberman, A. Michael. Qualitative Data Analysis. $2^{\text {nd }}$ ed., Thousand Oaks, CA: Sage Publications, Inc, 1994).

Minarik, Melanie, Thornton, M. Bill and Perreault, George. "Systems Thinking Can Improve Teacher Retention", Clearing House 76, no. 5 (2003): 230-234.

Mohd Juraimy Hj. Kadir and Ahmad Azan Ridzuan. "Strategi Menguruskan Tekanan dari Perspektif Islam (Stress Management Strategy in Islamic Perspective)". Jurnal Hadhari: An International Journal 6, no. 1 (2014): 27-41.

Moss, Charles A. "Power of the Five Elements: Path to Healthy Aging and Stress Resistance" retrieved on April 20, 2010, http:///northatindiabooks, wordpress.com.

National Council on Teacher Quality. State Teacher Policy Yearbook: What States Can Do to Retain Effective New Teachers. Washington, DC: Author, 2008.

Newberry, Melissa and Allsop, Yvonne. "Teacher Attrition in the USA: The Relational Elements in a Utah Case Study". Teachers and Teaching 23 (2017): 863-880. 
Norhafizah Musa and Che Zarrina Sa'ari. "Pendekatan Psikoterapi Islam dalam Menguruskan Tekanan Pesakit Kronik", Jurnal Usuluddin 47, no. 1 (2019): 1-34.

Nurul Sakinah Aziz et al. "Psycho-Spiritual Treatment: An Exploratory Study on Its Practices". Journal of Critical Reviews 7, no. 8 (2020): 1007-1011.

Othman, Khatijah and Sipon, Sapora. "Researching Solution Based on Islamic Views and Practice in Managing Financial and Work Place Stress", International Journal of Academic Research in Business and Social Sciences 2, no. 8 (2012): 239-252.

Othman, Khatijah and Sipon, Sapora. "The relationship of Financial Stress and Religious Coping from Islamic Perspective", International Review of Management and Business Research 3, no. 1 (2014): 133.

Pargament, K.I. Spiritually Integrated Psychotherapy: Understanding and Addressing the Sacred. New York: Guilford, 2007.

Ramly Radzi et al., "Religious and Spiritual Coping Used by Student in Dealing with Stress and Anxiety". International Journal of Asian Social Science 4 (2014): 314-319.

Ronfeldt, M. Loeb, S. and Wyckoff, J. "How Teacher Turnover Harms Student Achievement", American Educational Research Journal 50 (2013), 4-36.

Safe, Siti Noorshafenas dan Nor, Ahmad Yunus Mohd. "Pengurusan Stres Menurut Al-Quran dan Hadith". Al-Hikmah 8, no. 1 (2016): 3-18.

Selye, Hans. "A Personal Message from Hans Selye". Journal of Extension 18, no. 3 (1980): 6-11.

Selye, Hans. "Stress without Distress". In Psychopathology of human adaptation. Boston, MA: Springer, 1976.

Sezer, Senol. "Novice Teachers' Opinions on Students' Disruptive Behaviours: A Case Study." Eurasian Journal of Educational Research 69 (2017): 199-219.

Shahid Athar, M.D. Islamic Perspective in Stress Management. https://www.islamicity.org/6575/islamic-perspective-in-stressmanagement (2017).

Sharplin, Elaine, Marnie O’Neill, and Anne Chapman. "Coping Strategies for Adaptation to New Teacher Appointments: 
Intervention for Retention", Teaching and Teacher Education 27, no. 1 (2011): 136-146.

Shohani, Saeedeh, et al."The Relationship between Novice and Experienced Teachers' Self-Efficacy for Personal Teaching and External Influences." Procedia - Social and Behavioral Sciences 185 (2014): 446-452.

Siti Chodijah. "The Concept of Tahajud Prayer Through Psychotherapy Approach in Relationship with Psychological Health". In Proceedings of the 1st International Conference on Innovative Pedagogy (Icip) 2017. Stkip Bina Bangsa Getsempena, 2017: 324-330

Sorenson, Richard D. "Stress Management in Education: Warning Signs and Coping Mechanisms", Management in Education 21, no. 3 (2007):10-13.

Struyven, Katrien Dochy, Filip and Janssens, Steven. "Teach as You Preach: The Effects of Student-Centred versus LectureBased Teaching on Student Teachers' Approach to Teaching," European Journal of Teacher Education 33, no. 1 (2010): 44-64. Struyven, Katrien, Filip Dochy, and Steven Janssens. "'Teach as You Preach': The Effects of Student-Centred versus LectureBased Teaching on Student Teachers' Approach to Teaching." European Journal of Teacher Education 33, no. 1 (2010): 43-64. Taylor, Michelle, et al. "The influence of multiple life stressors during Teacher Training on Burnout and Career Optimism in the first year of teaching". Teaching and Teacher Education 86 (2019): 1-11.

Triantoro, S. 'Are Leadership Practices, Role Stressor, Religious Coping, and Job Insecurity Predictors of Job Stress Among University Teachers? A Moderated-Mediated Model.' International Journal of Research Studies in Psychology 3 (2014): 87-99.

Utami, Tri Niswati. "Tinjauan Literatur Mekanisme Zikir Terhadap Kesehatan: Respons Imunitas". JUMANTIK (Jurnal Ilmiah Penelitian Kesehatan) 2, no. 1 (2017): 100-110.

Yin, Robert K. Qualitative Research from Start to Finish. New York: The Guilford Press, 2011.

Yousef Aazami and Esfandiar Azad Marzabadi. "Stress Management Model Pattern According to Quran and Hadith", Int J Behav Sci 10, no. 4 (2017): 167-175. 
Zakaria Mohd Arif, Arumugam Raman, and Yahya Don. "The Influence of Emotional Quotient (EQ) Towards Novice Teachers' Work Stress and Organizational Commitment". International Journal of Academic Research and Development 2, no. 2 (2017):11-17. 